\section{The Icefield Ranges Research Project, 1975 and 1976}

During 1975 and 1976, research staff and students occupied the base camp of the Icefield Ranges Research Project (IRRP) at Kluane Lake $\left(61^{\circ} \mathrm{N}, 138^{\circ} 30^{\prime} \mathrm{W}\right)$ from early April to mid-October. Altogether 126 individuals representing universities and institutes in Canada and the United States made use of the field research facilities during these two years. A decrease from 3,200 mandays of accomodation and subsistence in 1975 to 2,700 in 1976 reflected increasing difficulties in obtaining funds for field research in the North.

Adverse weather in the St. Elias Mountains in 1976 caused several projects to be severely restricted. Poor radio conditions and aircraft operational problems provided further difficulties. At one time both of AINA's ski-equiped Helio-Courier aircraft were out of commission. While deep in the mountains, one suffered broken landing gear and damage to other essential parts, but with the help of some ingenuity and hard work it was eventually flown out. A change of engine, also in the field, had to be carried out on the other plane which gave only indifferent service for the remainder of the season. In 1976, however, generally good weather conditions prevailed, radio communications were vastly improved, the aircraft remained airborne and the projects prospered.

Several improvements were made to the base camp itself. Storage facilities were extended so that the handling of equipment and materials was eased and more work space made available for researchers. A new generating plant was installed in 1975. Provision of a winterized workshop has made it possible to carry out aircraft maintenance and produce pre-fabricated camp buildings during the winter.

In cooperation with Parks Canada and Environment Canada, a year-round meteorological programme was carried out during 1975 and 1976 at the base camp by the camp manager, A. Williams. Automatic weather stations were maintained at Divide and at two sites on Bullion Creek in the Kluane National Park.

\section{HIGH ALTITUDE PHYSIOLOGY STUDIES (HAPS)}

The ninth year of field operations was satisfactorily completed in 1976 under the direction of C. S. Houston of the College of Medicine, University of Vermont.

For the second year volunteers were engaged to serve both as subjects and as sup- port members of the research team. Sixteen volunteers were chosen from over sixty applicants. Of these, five were medical, and three pre-medical, students (five were women). All were selected for their mountaineering and cold-weather experience, their scientific and career interests, and their personalities.

In the past, the most troublesome aspect of HAPS has been the uncertainty of weather conditions. It has seldom been possible to adhere to the schedules planned for the various camps or to be certain that subjects would reach the camp at Logan High after enough, yet not too long, stay at intermediate altitude. (Unlike during the first daring years of HAPS, persons are no longer flown directly from Kluane Lake to Logan High because of the serious risk of altitude illness entailed.) In 1975, weather was particularly unpredictable. Plans for 1976 were therefore designed to minimize the possible effects of weather by allowing for more flexibility with the scheduling of flights. The revised programme enabled a more extensive study to be made of human adaptation to altitude.

Two test groups were involved. After being subjected to baseline observations at McMaster University, Hamilton, Ontario (less than $100 \mathrm{~m}$ in altitude), the seven subjects in the first group were flown to Kluane Lake (780 m) and, after several days there, to a new site in Trench $(3,290 \mathrm{~m})$. They remained there for several days and then began their climb to Logan High $(5,330 \mathrm{~m})$. Five of them reached there on 15 June. A month later, after they were well-acclimatized, observations of their physiological state were made and recorded. The nine subjects of the second group were likewise subjected to baseline observations. Then on $\mathbf{3 0}$ June they were flown to Kluane Lake together with the scientific group. Several days later they were flown to Trench where they were again examined physiologically. After a further four days they started the climb to Logan High, arriving on 19 July, a week after the scientists had been flown up from Trench, and just after examination of the first test group had been completed. Tests on the second group were completed on 23 July.

As a result of the programme, good data were available on seventeen persons at 760 $\mathrm{m}$, on ten at $3,290 \mathrm{~m}$, on five after four weeks of adaptation at $5,330 \mathrm{~m}$, and on nine upon arrival at $5,330 \mathrm{~m}$

Although it will be some time before all the data assembled have been carefully analysed, it would appear that the studies of the research subjects in sleep have been especially important, involving as they did a 
continuous monitoring of the electro-encephalograms and oxygen saturation levels. Analyses were completed of the ventilatory system, hormones and blood of the research subjects while they were at rest, as well as before and during bicycle exercise of several degrees of strenuousness. Existence of a cause-and-effect relationship between exertion and haemorrhaging appears to have been confirmed. Urine samples were obtained and stored for later analysis, and serum samples were frozen and kept for later hormone assays. Clinical observations of the subjects were recorded daily.

\section{GLACIER INVENTORY OF ST, ELIAS MOUNTAINS}

1976 was the last year of a three-year study of ice features in those portions of the St. Elias Mountains which are drained by the Yukon and Alsek rivers and lie entirely within Canada. The study area included much of Kluane National Park and extended southward into the northwestern corner of British Columbia.

R. H. Ragle and S. G. Collins, co-investigators, have made use of aerial photographs, existing topographical maps and a wide selection of library sources to produce thematic maps, computer-accessible data files, and an extensive bibliography on glaciers and related snow and ice features. $A$ total of 3,456 glacier features, each with a unique inventory number, have been catalogued, described, and located on regional and large-scale maps. The whole compilation, of fundamental importance for future glaciological research, forms part of the $\mathrm{Ca}$ nadian contribution to the World Glacier Inventory of the International Hydrological Decade, promoted by the International Association for Scientific Hydrology (UNESCO).

AINA's participation in the Canadian Glacier Inventory ended in 1976. Further work on it will be undertaken within the Glaciology Division of Environment Canada, and under the auspices of various Canadian universities, especially the University of British Columbia.

\section{GLACIER GEOPHYSICS PROJECTS}

Under the direction of G.K.C. Clarke of the University of British Columbia, aerial depth surveys were carried out in 1976 over three surge-type glaciers in the Steele Glacier region using the 840 -megahertz highresolution radar system developed by B. B. Narod, G. K. C. Clarke and R. H. Goodman. While the radar survey was being performed - from a Bell 206 helicopter - vertical aerial photographs were being simultaneously taken to provide the record of the flight lines from which ice-thickness maps will be constructed. In addition, a single depth profile was recorded by radar in the vicinity of the proposed Mount Logan corehole site, which should be of help in future site selection (maximum ice thickness near AINA's Mount Logan camp is 350 metres), and measurements of electromagnetic birefringence of ice were made - also by radar - from the surface of Hazard Glacier by B. B. Narod.

Field testing of a hot-water circulating ice drill was carried out by J. G. Napoleoni, S. G. Collins and G. K. C. Clarke on the Hazard Glacier, and drilling rates of over 120 metres per hour were achieved. The depths of the holes made ranged from 110 metres at a site toward the snout of the glacier to 220 metres in its middle zone. Thermistor cables were let into three of them, all presumed to have reached the rock bed, to facilitate the making of ice-temperature measurements.

Using a theodolite and laser ranger, S. G. Collins carried out a levelling survey of $\mathrm{Haz}$ ard Glacier, the results of which will provide useful control data for a base map. Since Hazard Glacier is a surging glacier, the configuration of its bed, its present surface profile and its thermal regime are of particular interest. Hazard Lake, the icedammed lake formed as a result of the Steele Glacier surge of 1965-66, has now drained through a sub-glacial channel. The drainage, which occurred between July 1975 and July 1976, appears to have been uneventful, with no sign of flooding.

In July 1975, work on the Mount Logan topographical survey was concentrated in the area of the northwest col; subsequently a provisional map of the area was produced at a scale of 1:10,000. On the col itself a 16metre hole was drilled using a SIPRE corer; the core has since been analysed for tritium and oxygen isotopes. A strain diamond was installed on the col and some depth sounding done at the AINA camp at Logan High.

In July and August 1976, two 8-metre cores were retrieved to check the previous isotope results and to provide samples for pollen analysis. The net accumulation on the northwest col was measured and the strain diamond was resurveyed. G. K. C. Clarke obtained ice-depth data by radio-echosounding during a flight over the col. Additional surveying (including occupation of the west peak by theodolite) was carried out with the object of extending the coverage provided by the map produced in 1975 . 
ENVIRONMENTAL CONTROLS ON GEOMORPHIC PROCESSES

A field party of eleven, including the study director, P. G. Johnson of the University of Ottawa, W. G. Nickling and D. Cossette, carried out a six-week project in the Grizzly Creek area of the Kluane National Park, the main elements of which were: studying the critical role of stream action in the control of the erosional processes on an icecored moraine system; abtaining further data for the study of the rates of activity of climatic processes; taking measurements of the stage, discharge and suspended load of the glacier-fed stream (complications were however caused by periodic rapid discharge through the ice core of the moraine system); taking measurements of rock glaciers in order to determine the patterns of movement of various types of these landforms; and making a biological inventory and detailed plantcommunity analysis of the region.

\section{STUDY OF SMALL MAMMALS}

The 1976 summer season was the fourth of a study, conducted by the Institute of Animal Research Ecology of the University of British Columbia, of the population cycling of mice. The data so far collected with the aid of seven 100-trap grids for live trapping, each approximately 150 metres square and together so located that all mouse habitats are represented and all species sampled - provide further support for the "genetic selection" theory of population cycles of small mammals. In 1976, two more of the same grids were added in a forest habitat to obtain more information on Peromyscus spp., and sample size was increased as a result of snap trapping over a wide area in all habitats; and, in addition, five grids for live trapping, each approximately 300 metres square, were staked out as an initial step in a study of the population cycling of snowshoe hare.

\section{ACKNOWLEDGEMENTS}

The Arctic Institute gratefully acknowledges financial and other support for the Icefield Ranges Research Project (IRRP) received from the Canadian Forces, Defence and Civil Institute of Medicine, Environment Canada, the Government of the Yukon Territory, Parks Canada, and the U.S. National Institutes of Health. For funding of the project on environmental controls on geomorphic processes, the Institute is indebted to the National Research Council of Canada, the Northern Studies Group of the University of Ottawa and the Royal Canadian Geographical Society.

\section{Election of Fellows}

The following were elected Fellows of the Arctic Institute of North America at the meeting of the Board of Governors held on 2 December 1975:

Miss Vivian Bushnell, Largo, Florida Miss Margery Hinds, Victoria, British Columbia

The following were elected Fellows of the Institute at the meeting of the Board of Governors held on 15 November 1976:

Professor Leo Aario, Tapiola, Espoo, Finland

Dr. Vera Alexander, Fairbanks, Alaska

Dr. Thomas W. Barry, Edmonton, Alberta

Dr. Jerry Brown, Hanover, New Hampshire

Mr. Fred Bruemmer, Montreal, Quebec

Dr. Angus Bruneau, St. John's, Newfoundland

Dr. Garry K. Clarke, Vancouver, British Columbia

Dr. James B. Cragg, Calgary, Alberta

Mr. Louis L. De Goes, Washington, D.C.

Dr. Kaye R. Everett, Columbus, Ohio

Mr. Frank Fisher, Anchorage, Alaska

Dr. Kenneth M. Knoll, Houston, Texas

Mr. Joseph H. Kravitz, Potomac, Maryland

Dr. Willard N. Larsen, Anchorage, Alaska

Mr. Costa H. Liljequist, Uppsala, Sweden

Dr. Allen P. McCartney, Fayetteville, Arkansas

Mr. Ronald K. McGregor, Arlington, Virginia

Professor Maynard Miller, East Lansing, Michigan

Mr. John Havelock Parker, Yellowknife, Northwest Territories

Dr. William L. Ryan, Anchorage, Alaska

Dr. Thomas G. Smith, Ste. Anne de Bellevue, Quebec

Dr. Morris Zaslow, London, Ontario

Mr. William Zeigler, Edmonton, Alberta

Also elected on 15 November 1976 were Doctors of Geographical Sciences of the U.S.S.R. E. K. Fedorov, E. I. Tolstikov and A. F. Treshnikov. 